\title{
ADRB1 wt Allele
}

National Cancer Institute

\section{Source}

National Cancer Institute. ADRB1 wt Allele. NCI Thesaurus. Code C51429.

Human ADRB1 wild-type allele is located within 10q24-q26 and is approximately $2 \mathrm{~kb}$ in length. This allele, which encodes beta-1 adrenergic receptor protein, is involved in the mediation of hormonal physiological effects from epinephrine and norepinephrine. Select polymorphisms of the gene have been shown to affect resting heart rate function and if dysregulated, can be involved in heart failure. 